\title{
GENDER EQUITY, SOCIAL INSTITUTIONS AND THE FUTURE OF FERTILITY
}

\author{
Peter McDonald $\dagger$ The Australian National University
}

Sustained very low levels of fertility in advanced countries can be explained by incoherence between the levels of gender equity applying in different social institutions. In countries with very low levels of fertility, high levels of gender equity are postulated in institutions that deal with people as individuals, while low levels of gender equity apply in institutions that deal with people as members of families.

The persistence of very low levels of fertility in many advanced countries has added a new dimension to the development of theory relating to fertility change. This paper proposes a general theoretical explanation of these very low levels of fertility by building upon the empirical work and theory-building of several previous studies: Lesthaeghe and Surkyn (1988), Folbre (1994), McNicoll (1994), Greenhalgh (1995), Hobcraft and Kiernan (1995), Chesnais (1996), Hobcraft (1996), Micheli (1996), Rindfuss, Brewster and Kavee (1996), Rindfuss, Morgan and Offutt (1996), van de Kaa (1996), and, most importantly, Esping-Andersen (1996). The thrust of the argument is that very low levels of fertility in advanced countries today can be explained in terms of incoherence between the levels of gender equity applying in different social institutions. In countries with very low levels of fertility, it is postulated that the levels of gender equity in institutions that deal with people as individuals, such as education and market employment, will be high while, on the other hand, the levels of gender equity applying in institutions that deal with people as members of families, such as industrial relations (the terms and conditions of employment), services, government transfers, and the family itself, will be low.

Put more simply and in terms similar to those already expressed by others (Chesnais 1996:738; Esping-Andersen 1996:67), if women are provided with opportunities nearly equivalent to those of men in education and market employment, but these opportunities are severely curtailed by having children, then, on average, women will restrict the number of children that they have to an extent which leaves fertility at a precariously low, long-term level.

\section{The context of very low fertility}

An understanding of these very low levels of fertility is important because the present levels of fertility are so low that, if maintained in the long term, they would threaten

$\dagger$ Address for correspondence: Demography Program, Research School of Social Sciences, The Australian National University, Canberra ACT 0200, Australia. 
the future existence of the peoples concerned. For example, in a stable population with the level of fertility applying in 1995 in Italy, population size would drop in just 100 years to only 14 per cent of its initial level (assuming the replacement level of the total fertility rate is 2.1 and the length of the generation is 30 years). The corresponding percentages consistent with the 1995 fertility levels of some other countries with very low fertility axe 15 per cent for Spain, 17 per cent for Germany, 26 per cent for Greece and 28 per cent for Japan. Even with a total fertility rate of 1.7, the level applying in France in 1995, a stable population would fall to 50 per cent of its initial size in a 100year period. In 1985, Teitelbaum and Winter referred to the tendency for societies in fear of population decline to adopt pronatalist policies 'verging on the draconian', and this was said in the context of what the authors saw as the 'future slow growth (or even decline)' of the populations of Western countries (Teitelbaum and Winter 1985:1-2). With knowledge of the fertility rates of the past decade, these authors might have been even more urgent in their concern about the possibility of pronatalist policies verging on the Draconian.

It is important to consider also that the average fertility level may distort the story of low fertility. When fertility is generally low, it will become very low through the decisions of some women, not all women. If 20 per cent of women have no children and 20 per cent have one child, then this 40 per cent of women are contributing only 0.2 children to the total fertility rate. For such a society to have replacement-level fertility, the remaining 60 per cent of women would have to have an average of 3.2 children each. This is extremely unlikely in societies today where the norm for those planning to have children is to have two children. At the other end of the fertility distribution, a comparison of fertility by birth order in Italy and in Australia in 1991 shows that some 70 per cent of the additional fertility in Australia compared to Italy was due to births of order three and above. Giorgi (1993) has shown that the total second- and third-order birth rates account for most of the drop in Italian fertility over the past 20 years, that is, mothers are stopping at one or two children. Thus, the argument about very low fertility is not simply about women having no children, but about some women having fewer children than they might otherwise have had. Chesnais (1996), for example, reports that achieved fertility in Italy is well below desired fertility. A similar finding applies to Japan (Retherford, Ogawa and Sakamoto 1996).

In an era in which we have come to understand the momentum of population increase, it is remarkable that we are yet to appreciate that the same momentum applies to population decrease. Furthermore, with very low fertility, as the population decreases in size, it also ages extremely rapidly to form an age structure in the shape of an inverted pyramid. In these potential future populations, there will be many more people aged 75 years and over than will be aged 20 years and under. It is again remarkable, given the knowledge that fertility is the dominant determinant of age structure, that the numerous studies of policies for ageing societies pay so little attention to fertility. Indeed, it is argued in this paper that new liberal economic policies designed to deal with ageing, such as cuts to government expenditure on family services and increased insecurity of employment, tend to depress fertility even further by making family life even less sustainable. As Esping-Andersen (1996:78) has said: 'The real demographic problem in continental Europe is not ageing but low fertility and low 
activity'.

Despite the current blinkered approach in most countries, it is inevitable that more and more countries will be seeking policies which aim to maintain fertility at levels closer to replacement level. That is, there seems little question that pronatalist policies will become a central part of the political agenda in the near future. The generally-held wisdom is that past and present pronatalist policies have been largely ineffective (McNicoll 1995). This wisdom is another factor that is temporarily holding down the demand for pronatalist policies, but future demand is inevitable. Better understanding of the causes of very low fertility will assist in defining policies that are both effective and socially responsible.

The countries in 1995 which had very low total fertility rates (below 1.5) were Italy, Spain, Germany, Austria, Switzerland, Greece, Portugal, Japan, Hong Kong and Macau (Monnier and de Guibert-Lantoine 1996; US Bureau of the Census, International Programs Center, Internet site). This list is somewhat surprising because most of these are countries with cultures that take pride in attaching a high value to families and in being socially conservative in regard to family functioning. The incidences of divorce, childbearing outside of marriage and relationships alternative to marriage are much or somewhat lower in these countries than in countries with higher fertility rates such as the Nordic countries and the English-speaking countries (Monnier and de Guibert-Lantoine 1996). They are also countries that express more conservative values in regard to the role of women, especially mothers. In regard to policies related to family services, taxation systems and industrial relations, all of the very low fertility countries have arrangements which make the employment of mothers more difficult than it is in the Nordic countries or in the English-speaking countries.

\section{Institutional models of family}

Throughout this century until the 1970s, the assumed institutional form of the family in all currently advanced countries was the male breadwinner, or family wage model under which the father goes out to work while the mother stays at home to look after the children. The principle underlying this model is that there is a natural differentiation between men and women which requires the man to be the provider and protector and the woman to be the carer and reproducer. The antithesis of the male breadwinner model of the family is the gender equity model. In the gender equity model of the family, there is income earning work, household maintenance work and caring and nurturing work, but gender has no specific relationship to who does which type of work. The gender equity model does not imply exact equality between the man and the woman in any heterosexual couple, rather that specific roles are not determined on the basis of gender. The principles upon which this model are based are equal respect for men and women, equality of resources and capabilities, parity of participation in socially valued activities, and an end to male-centred measures of social value (Fraser 1994).

The male breadwinner model reached its zenith in the 1950s when Parsons and Bales (1955) described it as being ideally suited to advanced capitalist societies which revolve around individual achievement and social and geographic mobility, and Bowlby (1953:15) referred to the father's role in regard to the children as one of keeping the 
mother in a harmonious, contented mood. Academic psychologists in the 1950s deemed all those who did not want to live in this family form as being socially deviant (Ehrenreich 1983). All other social and economic institutions were founded on the assumption that the male breadwinner model was the universal institutional form of the family. While women might be educated for reasons of gentility or to be better wives and mothers, the primary purpose of the education system was to produce the next generation of male breadwinners. Men were paid higher wages than women for the same work and employers were encouraged to favour men over women in the job selection process. In Australia, the great symbol of the hegemony of the male breadwinner model was the Basic Wage, a wage sufficient for a man to support a wife and three children. Introduced in 1907, it continued to be the foundation of the wagefixing system until 1973. Industrial relations was concerned with jobs and wages for men, not working conditions for parents. Trade unions and employer organizations were male-oriented. Child care services had no policy priority and were regarded as only serving the needs of unfortunate mothers who did not have the support of a husband. The breadwinner model was the basis of the tax-transfer system with allowances for children being directed to the wallet rather than to the purse. Social security and social insurance systems also were premised and generally still are premised on the notion that the husband would be supporting the wife and children. In most countries, there were no benefits for sole mothers unless they had proved themselves deserving by being deserted by their male breadwinner. Women married early and had their children early because they were confident that their support was guaranteed by social and economic institutions. The relatively high fertility of the baby-boom era can be interpreted as a consequence of the coherence around the male breadwinner model of the family of all social and economic institutions (McDonald 1995).

In the past 30-40 years, different institutions in society have been moving away from the assumption of the male breadwinner model of the family in the direction of a gender equity model (Gilding 1997). They have done so, however, at differing speeds leading to substantial gaps between social and economic institutions in regard to the model of family that they presume. The theory proposed here is that it is these gaps or the extent of incoherence between social institutions in regard to the presumed model of family that leads to very low fertility. Among institutions most pertinent to the present argument, the assumption of the male breadwinner model has almost been eliminated from the institutions of education and market employment. Today, in almost all advanced countries, women are educated to the same standard as men and, in many countries now, to a higher standard. Women are educated for employment in the paid labour force just like men. Delay of childbearing and of the formation of long-term relationships mean that young women spend a considerable number of years in full-time, paid employment without the concern of care of children or, for that matter, care of partner. In most countries, there is equal pay for equal work and the level of discrimination against women in employment selection has been reduced substantially relative to the 1950 s through mechanisms such as equal employment opportunity legislation. Parents very actively encourage their daughters to pursue education and paid employment. Overall, a relatively high degree of gender equity applies in the institutions of education and market employment and this offers considerable 
opportunities to women to pursue roles other than that of mother.

As a consequence of these changes, the social and economic world of young people in all advanced countries today is very different from that faced by young people in the 1950s (McDonald 1996; Peron et al. 1999). The present generation of young women does not see its future in terms of the male breadwinner model of the family. Indeed, most would not stake their future living standard on the assumption that they will be fully dependent upon the earnings of a man. Likewise, many young men do not wish to be in a position where they are fully supporting a dependent wife. They see their own living standards being enhanced if their partner is also earning. Societies and economies have become geared to the two-income couple or the one-income single. These changes are reflected in the decline in fertility rates under the age of 25 years and in the high labour force participation rates for women aged 25-34 years, now the main childbearing ages in advanced countries. Ages 25-34 years have become the main ages for career advancement for young people while at the same time being the main reproductive ages for women.

In all advanced countries, however, institutions more related to family and parenthood have been much slower to move away from the male breadwinner model and to adapt to the new realities facing young people. This has placed pressure upon fertility rates in all countries, but where social and economic institutions have adapted more rapidly to the gender equity model, as in the Nordic countries, the English-speaking countries and in France, fertility has not fallen to very low levels. On the other hand, in countries where attitudes to the family have remained closer to the male breadwinner model, where employment for mothers has been restricted by lack of family support services (child care, school holiday care, aged care), where societal arrangements make it difficult to combine work and family (school hours, hours of work, employer expectations in regard to work and family priorities, leave conditions) or where the tax-transfer system remains geared to the male breadwinner model, fertility rates have plummeted. Countries differ on the extent of movement to gender equity in each of these social institutions, but the overall picture is that very low fertility countries have lower gender equity on average than do the countries that do not have very low fertility.

\section{The institution of the family and gender equity}

Among the social and economic institutions related to family which affect fertility rates, the most important is the family itself. Micheli (1996:39) points out that the very low fertility countries in Europe are those classified by Le Play in the nineteenth century as having 'the lineage (souche) family, characterized by enduring patriarchal stability'. The institutional or organizational form of the family constitutes an important part of a society's idealized morality. As such, family is one of the defining principles of the culture of every society and the family as an institution is very resistant to change (McDonald 1994).

The fertility rates of Greeks and Italians in Australia provide a particular example of the importance of family organization and idealized morality in the determination of fertility rates. Over the past 20 years, the fertility rates of both first and second generation Greekand Italian-Australians have followed the course of fertility in 
Greece and Italy respectively. In the mid-1970s, their fertility rates were above those of Australians of British-Irish origin and fertility occurred at relatively early ages. Now, their fertility rates are very low (TFR below 1.5) and their age patterns of fertility are the same as those in Italy and Greece and older than that of Australians of British-Irish origin (Abbassi Shavasi and McDonald 1996). At the same time, however, Australians of Greek and Italian origin continue to adhere to conservative attitudes to the family and to the superiority of the adult male in the family context (McDonald 1991; Tsolidis 1995; Vasta 1995; Khoo and Shu 1996). As large groups in a multicultural society, Italian-Australians and Greek-Australians have been able to maintain significant features of their culture. The incidences of divorce, ex-nuptial births and relationships alternative to marriage are much lower than they are in the dominant culture, and patriarchy prevails. At the same time, young women of Italian and Greek origin in Australia, now mainly of the second generation, have the same opportunities and achievements of other Australians in education and in market employment. Conditions applying in other Australian institutions related to family, such as family services, tax and social security and industrial relations apply to Italian and Greek Australians in the same way as they do to all other Australians; however, family organization or morality modifies use of or access to these conditions. For example, among southern Europeans in Australia, care of dependent members, young or old, sick or disabled, is considered to be the responsibility of the family, more especially its female members. As a consequence, family support services provided by government, by voluntary organizations or by the market, while available, are used only as a last resort (Vasta 1995). Thus, in this 'social experiment' in which all else is controlled other than the nature of family organization, fertility rates are very low for groups whose family organization remains closer to the male breadwinner model.

Using a cross-national, legislative perspective, Therborn (1993) has established that there is a strong relationship between the development of children's rights in Western nations and the forms of legal patriarchy that applied at the beginning of this century and which still persist to varying degrees. He divides children's rights into three categories: the child-centred family (equal parental rights and the best interest of the child as a paramount principle); equality between children of married and non-married parents; and integrity (restraints on child abuse by parents). It is striking that Therborn's classification of countries into four groups in terms of the timing of movement towards children's rights and away from patriarchy bears a close resemblance to groups based upon current fertility levels. Change occurred first in the Nordic countries, then in the English-speaking countries, then in the Germanic countries and finally in the southern European countries. It is an interesting proposition indeed that fertility is lowest in countries which have a long tradition 'of protecting males from the consequences of their sexuality at the expense of the rights of children' (Therborn 1993:263), but, more generally, it is perhaps not surprising that fertility is higher where the law has a longer tradition of valuing children. The law provides a good reflection of idealized family morality. If patriarchy is enshrined in the law, or if its removal from the law is of recent origin, then the idealized morality of the family can also be expected to be patriarchal, and hence, of a male breadwinner form.

Family organization in East Asian countries is also male-dominated and fertility in 
these countries, led by Japan, is falling to very low levels. Fertility in Hong Kong, Macau, South Korea, Taiwan and Singapore is already below the current levels in the Nordic countries and in English-speaking countries. In these Asian countries, however, a woman's status tends to decline substantially upon marriage rather than upon the birth of a child and as a consequence, marriage rates have dropped sharply for women, most particularly for more highly educated women (Jones 1995). Single women are able to be economically and socially independent and this is what many now prefer. Nonmarriage then becomes part of the explanation of low fertility, but lying behind it is the combination of a patriarchal family structure with relative gender equity in education and market employment.

In the advanced countries which do not have low fertility, gender equity within the family is more advanced. The early experience of intimate relationships of young people is often of non-marital relationships in which the underlying principle is that each member contributes half of the expenses (Singh and Lindsay 1996). Often also, the young woman in the relationship is earning more than her male partner, presuming a heterosexual relationship. She often also has a higher level of education. Because the main purpose of the relationship is the relationship, like Anthony Giddens's pure relationships (Giddens 1992), the relationships of young people are vulnerable. Many have also experienced the ending of the relationships of their parents and have seen their mothers, or much less often, their fathers, left in financially dependent or precarious situations (McDonald 1986). The recognition that relationships are vulnerable means that young women believe that they need to be in a position where they are able to support themselves financially. Mothers and fathers of young women tend to support this direction as do young men. The movement towards gender equity within the family in Nordic and English-speaking countries has been documented in studies of changing family values (Glezer 1982; Lesthaeghe and Meekers 1986; Palomba and Moors 1993; Evans and Mason 1996; Rindfuss, Brewster and Kavee 1996). The values shown in Table 1 were derived from a national random survey of Australians conducted by the Australian National University in November 1996. The data show that, at least in terms of expressed values, a large majority of Australians, both men and women, have adopted the gender equity model. Not shown in the table, however, is the fact that women are much more likely than men to agree strongly with each of the propositions. Research in Australia also has shown that men's behaviour lags considerably behind their expressed attitudes and values (Glezer 1982). Even in Sweden, where the conditions of women's employment are highly favourable, there is a considerable degree of occupational segregation of men and women (Hoem 1995). Thus, gender inequity is still prevalent in all countries, but some countries have made considerable change while others are resistant to change because of the strength of the underlying idealized family morality.

A similarly-worded item to the third item in Table 1 has been asked in surveys in the United States over a long period. The level of community agreement in 1991 was about the same as it was in Australia in 1996. Furthermore, between 1970 and 1991, the percentage of married women of childbearing age in the United States who agreed that it is better for everyone involved if the man is the achiever outside the home and the woman takes care of the home and family fell from 80 to 27 per cent (Rindfuss, Brewster and Kavee 
Table 1 Gender equity values in Australia, Australians aged 18-54 years, 1996

\begin{tabular}{|c|c|c|}
\hline \multirow{2}{*}{ Statement } & \multicolumn{2}{|c|}{ Per cent agreeing } \\
\hline & Men & Women \\
\hline $\begin{array}{l}\text { If both the husband and wife work, they should share equally in } \\
\text { the housework and care of the children }\end{array}$ & 95 & 95 \\
\hline $\begin{array}{l}\text { There should be satisfactory child care facilities so that women } \\
\text { can take jobs outside the home }\end{array}$ & 88 & 93 \\
\hline $\begin{array}{l}\text { It is better for the family if the husband is the principal } \\
\text { breadwinner and the wife has primary responsibility for the } \\
\text { home and the children }\end{array}$ & 34 & 31 \\
\hline $\begin{array}{l}\text { Ideally, there should be as many women as men in important } \\
\text { positions in business and government }\end{array}$ & 84 & 88 \\
\hline
\end{tabular}

Source: Negotiating the Life Course Survey, Research School of Social Sciences, The Australian National University, November 1996.

1996:469). In contrast, a similarly-worded question attracted 64 per cent agreement from Japanese women in 1993 and 75 per cent from Japanese men (Retherford et al. 1996).

Studies of family formation in Australia have shown that there seems to be an increasing tendency for the man to hold back and leave the decision about the timing of a first child to the woman. Most men still approach having a child with the view that the child will have little impact on their own work force participation, but young men today are considerably more sensitive than older generations to the impact that a child will have on their partner's work force participation. Men concerned about the impact of the loss of the wife's income on their own standard of living may actively discourage childbearing. In the next generation, which will be more sensitive to gender equity, the need to maintain equity in the relationship will also be an important reason that a birth may be delayed or never occur. Loss of equity may be too great a threat to the relationship.

\section{Gender equity as reflected in income transfer systems, services and industrial relations}

Other social institutions, either explicitly or implicitly, are modelled upon assumptions about the nature of family organization in the society. Government or government-approved income transfer arrangements frequently remain modelled upon the male breadwinner family. For example, occupationally-related social insurance or social welfare schemes, common in Continental Europe, favour men over women where women's employment is limited by childbearing. Earnings-based benefit calculations in such schemes assume the male breadwinner model of family as they are likely to provide much higher benefits to men than to women. While such schemes may be seen as providing an incentive for women to work, the incentive only applies fully if women are fully committed to work, which is difficult in these countries if the women are mothers. Of course, such schemes also have social equity implications but the effect of social inequity on fertility is complex. 
Arrangements for joint income tax for couples are usually structured so that joint after-tax income is highest when the income is earned by one person and lowest when the two persons earn the same amount. This occurs if the rates of taxation by income level are progressive or if tax deductions or rebates are provided for a dependent spouse. Such structures can provide substantial work disincentives for the partner of an income earner (Zimmermann 1993; Gustavsson and Stafford 1994). Esping-Andersen (1996) has provided calculations which show that the tax system in Sweden is neutral to the size of the wife's earnings and the effect is modest in France (an elasticity of 0.93). However, the impact is greater in other countries (an elasticity of 0.71 in Belgium, 0.58 in Germany and 0.52 in the Netherlands). Near-neutrality also applies in Australia, but the Australian system has become less neutral from 1997 when a new tax concession for one-income families was introduced. Transfers through the tax system, including lower taxes and tax rebates for children, are usually paid in greater proportion to men than to women. Men are less likely than women to direct this money into the purchase of family services. In countries with tax systems that are not punitive to the earnings of a second earner, fertility is higher.

The division of countries on the basis of fertility levels mirrors Esping-Andersen's classification of welfare systems. He says that the Continental European countries, in sharp contrast to the Nordic countries, are 'service-lean yet very transfer-heavy', that is, while they may provide money to families in the form of transfers, they score poorly in the provision of family services. He shows that the ratio of expenditure on services to expenditure on transfers is 0.33 in Denmark and 0.29 in Sweden, but 0.16 in Germany and 0.06 in Italy (Esping-Andersen 1996:67-71). In social systems that have not moved fully to gender equity (the situation in all societies), expenditure on services usually provides greater benefits to women than to men, because women are more likely to be the substitute providers of family services if these services are not provided by the state or by the market. Thus, expenditure on tax transfers is consistent with the male breadwinner model of the family while expenditure on services is consistent with a gender equity model. Obviously, among all family services, provision of child care is highly beneficial to the employment of women and hence to a higher level of gender equity. However, the argument applies also to other services including services for aged persons, education, health and housing services. Again, low expenditure on family services matches low fertility.

Besides the provision of child care, Gustavsson and Stafford (1994) have argued that the relatively high fertility in Sweden (at least to the early 1990s) was related to more flexible working conditions, such as the availability of part-time work, flexi-time and liberal conditions for absence. Chesnais (1996) has recently documented the less favourable conditions relating to the employment of mothers in Italy and Germany in comparison to Sweden. In Germany, a mismatch between the hours in which schools are open and the hours that paid employment is available makes it more difficult than in other countries for a parent to work only during the hours that his or her children are at school. In general, countries which have low levels of part-time work also have very low levels of fertility. According to the OECD (1994:198), the percentages of employed women who were employed on a part-time basis in 1993 were 48 per cent in Norway, 45 per cent in the United Kingdom, 42 per cent in Australia, 41 per cent in 


\section{Peter McDonald}

Sweden, 37 per cent in Denmark, 36 per cent in New Zealand, 26 per cent in Canada and 25 per cent in the United States. On the other hand, the corresponding percentages in the very low fertility countries were 8 per cent for Greece, 11 per cent for Portugal, 12 per cent for Italy, 14 per cent in Spain, 21 per cent in Austria and 31 per cent in Germany. If the gender equity model of the family were to be fully implemented, these working conditions would be available to both parents regardless of gender. Again, this tends to be the case in the Nordic countries and is also the case in Australia. In practice, however, in the Nordic countries and in Australia, parental leave and part-time work are much more likely to be taken up by mothers than by fathers (Gray 2000). It can be argued, however, that greater use of these conditions by mothers is a necessary stage in the movement towards gender equity. In the future, when many more young women will have a higher earning capacity than their male partners, if these conditions are available to men, they will be more likely to be taken up by men. Again, fertility tends to be higher in countries that provide more familyfriendly working conditions.

\section{Gender equity, intergenerational equity and social equity}

Gender equity, intergenerational equity and social equity are not independent. The above discussion of the relationships between gender equity and fertility is directed to future childbearing and thus to young women and young men. Older generations who have benefited from past systems are often in the forefront of policy changes which make childbearing more difficult for the younger generation. The new liberal economic approach of small government and lower and flatter taxes redirects the nation's wealth from those with children to those without children. Goods and services taxes which provide no compensation for those with children obviously affect those with children to a much greater extent than those without children because children are consumers but do not earn income. Cutbacks in public provision of major services such as education and health services, or increases in charges for these services, affect those with dependants to a greater extent than those without dependants. For the mainstream of the population, having children is highly associated with feeling secure about one's financial future. This in turn is related to a sense of security about employment and housing. Unemployment, very low wages, increased job insecurity and large increases in the costs of housing, again all components of economic policies now in favour, provide a clear disincentive to people to have children. Ironically, these new liberal economic policies are often justified on the basis that societies need to prepare for the imminent burden of ageing of the population (National Commission of Audit 1996), yet the intergenerational inequity that they imply will make ageing a far greater problem through its impact on fertility.

It is also argued that the range of new liberal economic policies referred to above, through their effect on the labour market, produce a group who are outside the normal opportunity structure irrespective of whether they have children (Esping-Andersen 1996). For this group, nothing is lost by having children because they have no opportunity to succeed in the mainstream economy. By having children, they are able to participate in family life which at least provides some meaning to life. Hence, present policy directions may lead to both those at the very top and those at the very bottom 
of the income distribution being more likely to have children while childbearing is restricted for those in the broad, middle range of incomes. From this perspective, low fertility is related to social equity. It is little wonder, in this environment, that the middle class may object to the state supporting the children of the poor when they themselves feel that they are unable to have the number of children that they would prefer. Gender equity also enters this picture because the principal targets of middle-class objection to state support of the poor have been poor mothers.

There are other examples of the interplay of gender equity, intergenerational equity and social equity. For example, if the couple is the taxation unit as distinct from the individual, the benefit of splitting of joint income between partners for tax purposes is generally much greater for high income-earning males than for low income-earning males. Government tax expenditure then is directed to wealthy males and away from the provision of child-related services and hence away from gender equity. As, on average, young men have lower incomes than older men, intergenerational equity is also associated with this form of social inequity. It is also the case that most oneincome couples with children are likely to have a much lower living standard than twoincome couples without children or one-income singles. Social transfers usually fall a long way short of making up the difference. In addition, a husband with dependent children and a dependent wife is in a much more vulnerable position when he comes to negotiate his individual contract with his employer. So men also may see themselves as being better off without children.

Now in agreement with the new liberal economic agenda, depressed economies are not conducive to childbearing. This would seem to be a substantial part of the story of rapid decline in the fertility rates of the former Eastern bloc countries in the 1990s. It has also been suggested that this decline may be related to the demise in the 1990s of a formerly superior system of state-provided family services in these countries (Chesnais 1996), a suggestion which is in keeping with the general arguments of this paper.

\section{Conclusion: policy directions in support of fertility}

This paper has argued that very low fertility as observed in many advanced countries today is the result of incoherence in the levels of gender equity inherent in social and economic institutions. Institutions which deal with women as individuals are more advanced in terms of gender equity than institutions which deal with women as mothers or members of families. There has been considerable advance in gender equity in the institutions of education and market employment. On the other hand, the male breadwinner model often remains paramount in the family itself, in services provision, in tax-transfer systems and in industrial relations. This leaves women with stark choices between children and employment, which, in turn, leads to some women having fewer children than they would like to have, and very low fertility. Palomba and Moors (1993:40) refer to the fact that women in Italy and the Netherlands often wanted to have more children, but, once they had become parents for the first time, structural obstacles arose through the lack of social organization and support for families with children.

The problem of very low fertility can be addressed by extreme measures such as withdrawal of access to the means of fertility control; allowing particular peoples, 


\section{Peter McDonald}

those with very low fertility, to disappear; dividing women into two classes, those who are in paid employment and those whose occupation is to produce children, with the latter being paid for childbearing; or reproducing children artificially. Such measures are presumed to be unacceptable. Beyond this, in theory, there are two policy choices: to roll back gender equity so that women have much reduced opportunity in education and market employment (a return to the full-scale breadwinner model of the 1950s), or to advance gender equity in social institutions related to the family so that women and men are able to combine market employment with having children. The first of these, a return to the 1950s, plainly, is unrealistic in all advanced countries today. The waves of feminism have already broken upon the shores. The institutions of education and market employment are not going to return to the 1950s. Hence, a more rapid shift to gender equity in all social institutions is the only feasible option.

The core change required is the one that is the most difficult. Gender equity needs to be promoted within the family itself. Changes in cultural values are slow and idealized family morality is resistant to change. The direct role of government in changing family values is limited. The study by Therborn (1993), however, shows that past legis lative actions taken by governments in relation to the status of children are related to current levels of gender equity. The issue here is whether legislation can lead social change or whether legislation follows social change. If it is the latter, the legislation to which Therborn refers will simply not occur in cultures that are reluctant to give up the dominance of adult males in family organization. However, all countries have made some of these legislative changes and this leaves hope that further legislative change is possible. In addition, as the status of women in education and market employment improves and women become more assertive, changes in the family may be more likely. Thus, countries with very low fertility should give consideration to the range of legislation that has been enacted in Nordic and English-speaking countries in relation to children's rights and gender equity. Change in the institution of the family is also possible on a generational basis; that is, it will always be difficult to exact changes in existing couple relationships, but a different socialization of children can lead to change in the next generation. In this regard and in other respects as well, human relations education based on a gender equity perspective can be included in school curricula. Young women have been the leaders of the movement towards gender equity. They need to be supported in this endeavour by governments and the media. These are positive initiatives, but on the negative side, the message can go out to men that they risk having no descendants if they do not change their own role within families.

Consideration needs also to be given to changing existing transfer systems, supply of family services and industrial relations policies in the directions described above which favour gender equity. With regard to fiscal policy, the notion that a liberal economic agenda can run hand-in-hand with a conservative family agenda is false. The conservative family agenda asks women to sacrifice themselves to a conservative family ideal in which they make all the sacrifices. Yet, at the same time, the liberal economic agenda offers women great rewards, but those rewards fall rapidly with each successive child. The future peopling of the society is the vast gulf in the logic of this liberal economic agenda. To this agenda, children are not producers in the market, so they are 
of little social value. Indeed, if they keep skilled women out of market employment or disrupt their performance, then children make a negative contribution to the liberal economic agenda.

The new liberal economic agenda is reversing the directions that have produced higher fertility in Nordic and English-speaking countries, and fertility rates in these countries have begun to fall again in recent years. The family-friendly industrial relations policies of the 1980s are being reversed in the interests of efficiency. And indeed, there is no question that it is more efficient for employers to hire people who will not be disturbed by the counter-demands of family responsibility. Work arrangements make it difficult to combine work and childrearing and the workplace still has a male breadwinner approach to its practices and procedures. The employee is expected to put the workplace first, to be available out-of-hours and not to have sick children or children who are on school holidays. The job insecurity implicit in individual contracts also implies that the worker can go without work for short periods or can move around the country at short notice. In the interests of fiscal responsibility, the level of access to family-related welfare services is being cut. Again, it is unquestionable that governments will save money if they do not provide these services. However, marketization and privatization, if not subsidized or closely monitored by government, will inevitably provide access more readily and at a higher quality to those who can afford to pay for family services. This direction also gives rise to the possibility of exploitation of people who can only work outside the formal economy, and raises questions about the quality of services that are provided. Cutting family services and lowering taxes is a breadwinner model approach. It does not allow for rewards to be made to those who make the sacrifices that have to be made to support this system in the long term. Using Australia as an example of this trend, the report of the National Commission of Audit that promotes a liberal economic agenda urges that support to families with children should be limited to poor families (1996:123). Thus, services like child care and education are placed on the cost-cutting agenda. The costs of raising children are defined by the Commission as a private responsibility. The message is: you had them, you pay for them. Also, after 20 years in which benefits for children have been paid in the form of cash to the mothers of the children, from 1997, the Australian government has reintroduced child allowances through the tax system which are means-tested and paid mainly to the principal earner. Women then become dependent upon men for purchase of family services, the breadwinner model again.

Chesnais (1996) recently characterized countries with very low fertility under the heading 'nations of families' while those with somewhat higher fertility were classified as 'nations of individuals'. The arguments in this paper lead to a different classification. The issue is not about families versus individuals but about the nature of the prevailing family organization, that is, whether family is characterized by male supremacy or by gender equity. Indeed, individualism is the result of the incoherence between a liberal economic agenda in combination with an insistence upon traditional, male-dominated family organization. It is this combination that is fatal to childbearing. The liberal economic agenda needs to find space in its program for children. This can only be achieved through programs that emphasize gender equity and programs which recognize that governments must be involved in providing very substantial transfers 
through services or money to those who have children. In short, policies need to give explicit recognition to the fact that children are valuable to the whole society, not just to their parents.

\section{References}

Abbasi-Shavazi, Mohammad Jalal and Peter McDonald. 1996. Immigrant fertility levels and patterns in Australia, 1977-1991: an own-children approach to the 1991 Census. Paper presented to the Eighth Biennial Conference of the Australian Population Association, Adelaide, 3-6 December.

Bowlby John. 1953. Child Care and the Growth of Love. Harmondsworth: Penguin Books.

Chesnais, Jean-Claude. 1996. Fertility, family and social policy in contemporary Western Europe. Population and Development Review 22(4):729-739.

Ehrenreich, Barbara. 1983. The Hearts of Men: American Dreams and the Flight from Commitment. Garden City NY: Anchor Press.

Esping-Andersen, Gosta. 1996. Welfare states without work: the impasse of labour shedding and familialism in Continental European social policy. Pp.66-87 in G. Esping-Andersen (ed.), Welfare States in Transition: National Adaptations in Glohal Economies. London: Sage Publications.

Evans, M.D.R. and Karen Oppenheim Mason. 1996. Currents and anchors: structure and change in Australian gender role attitudes, 1984-1989. Pp.275-302 in J.N. Baron, D.B. Grusky and D.J. Treiman (eds), Social Differentiation and Social Inequality: Essays in Honour of John Pock. Oxford: Westview Press.

Folbre, Nancy. 1994. Who Pays for the Kids: Gender and the Structures of Constraint. London: Routledge.

Fraser, Nancy: 1994. After the family wage: gender equity and the welfare state. Political Theory 22:591-618.

Giddens, Anthony. 1992. The Transformation of Intimacy: Sexuality, Love and Eroticism in Modern Societies. Cambridge: Polity Press.

Gilding, M. 1997. Australian Families. A Comparative Perspective. Melbourne: Longman.

Giorgi, Piero. 1993. Una rilettura della fecondita del momento per ordine di nascita in Italia net periodo 1950-1990 considerando la struttura per parita. Genus 49(3-4):177-204.

Gray, E. 2000 'Labour force status and workplace provisions: examining the relationship between work and parental involvement in couple families. Paper presented to the 2000 Annual Meeting of the Population Association of America, Los Angeles, 23-25 March.

Glezer, Helen. 1982. Changes in marriage and sex role attitudes among young married women: 1971-82. In Proceedings of the Australian Family Research Conference, Vol. 1. Melbourne: Australian Institute of Family Studies.

Greenhalgh, Susan. 1995. Anthropology theorizes reproduction: integrating practice, political economic, and feminist perspectives. In S. Greenhalgh (ed.), Situating Fertility: Anthropology and Demographic Inquiry. Cambridge: Cambridge University Press.

Gustavsson, S. and F Stafford. 1994. Three regimes of childcare: the United States, the Netherlands, and Sweden. Pp.333-362 in R. Blank (ed.), Social Protection versus Economic Flexibility. Chicago: University of Chicago Press.

Hobcraft, John. 1996. Fertility in England and Wales: a fifty year perspective. Population Studies 50(3):485-524.

Hobcraft, John and Kathleen Kiernan. 1995. Becoming a parent in Europe. Discussion Paper WSP/116, Welfare StateProgramme. London: The Toyota Centre, London School of Economics.

Hoem, B. 1995. The way to the gender segregated Swedish labour market. In K.O. Mason and A.-M. Jensen (eds), Gender and Family Cbange in Industrialized Countries. Oxford: Oxford University Press.

Jones, Gavin W. 1995. The demise of universal marriage in East and South-East Asia. Paper presented to The Continuing Demographic Transition: The John C. Caldwell Seminar, The Australian National University, 14-17 August.

Khoo, Siew-Ean and Jing Shu. 1996. Immigrant Family Formation Patterns in Australia. Canberra: Department of Immigration and Multicultural Affairs.

Lesthaeghe, Ron and Dominique Meekers. 1986, Value changes and the dimensions of familism in the 
European Community. European Journal of Population 2:225-268.

Lesthaeghe, R. and J. Surkyn. 1988. Cultural dynamics and economic theories of change. Population and Development Review 14(1):1-45.

McDonald, Peter (ed.). 1986. Settling Up: Property and Income Distribution on Divorce in Australia. Sydney: Prentice-Hall of Australia.

McDonald, Peter. 1991. Migrant family structure. In K. Funder (ed.), Images of Australian Families. Melbourne: Longman Cheshire.

McDonald, Peter. 1994. Families in developing countries: idealised morality and theories of family change. Pp.19-28 in L -J. Cho and M. Yada (eds), Tradition and Change in the Asian Family. Honolulu: East-West Center.

McDonald, P 1995. Families in Australia: A Socio-demographic Perspective. Melbourne: Australian Institute of Family Studies.

McDonald, P 1996. Young people in Australia today: a socio-demographic perspective. Pp.1-7 in R. Thanki and C. Thomson (eds), Mortgaging Our Future? Families and Young People in Australia. SPRC Reports and Proceedings No. 129. Sydney: University of New South Wales.

McNicoll, Geoffrey. 1994. Institutional analysis of fertility. In K. Lindahl-Kiessling and H. Landberg (eds), Population, Development and the Environment. Oxford: Oxford University Press.

McNicoll, Geoffrey. 1995. Institutional impediments to population policy in Australia. Working Papers in Demography No. 53. Canberra: The Australian National University.

Micheli, Giuseppe A. 1996. New patterns of family formation in Italy. Which tools for which interpretation. Genus 52(1-2):15-52.

Monnier, Alain and Catherine de Guibert-Lantoine. 1996. La conjoncture démographique: l'Europe et les pays développés d'outre-mer. Population 51(4-5):1005-1030.

National Commission of Audit. 1996. Report to the Commonwealth Government, June 1996. Canberra: Australian Government Publishing Service.

Organization for Economic Cooperation and Development (OECD). 1994. Employment Outlook. July 1994. Paris.

Palomba, Rosella and Hein Moors. 1993. Life-styles, values, and fertility intentions in a cross-cultural perspective. Pp.27-41 in International Population Conference, Montreal 1993, Vol. 1. Liège: International Union for the Scientific Study of Population.

Parsons, Talcott and Robert F: Bales. 1955. The Family: Socialization and Interaction Process. New York: Free Press of Glencoe.

Peron, Y., H. Desrosiers, H. Juby, E. Lapierre-Adamcyk, C. Le Bourdais, N. Marcil-Gratton and J. Mongeau. 1999. Canadian Families at the Approach of the Year 2000. Ottawa: Statistics Canada.

Retherford, Robert D., Naohiro Ogawa and Satomi Sakamoto. 1996. Values and fertility change in Japan. Population Studies 50(1):5-25.

Rindfuss, Ronald R., Karin L. Brewster and Andrew L. Kavee. 1996. Women, work, and children behavioural and attitudinal change in the United States. Population and Development Review 22(3):457-482.

Rindfuss, Ronald R., S. Phillip Morgan and Kate Offutt. 1996. Education and the changing age pattern of American fertility: 1963-1989. Demography 33(3):277-290.

Singh, Supriya and Jo Lindsay. 1996. Money in heterosexual relationships. Australian and New Zealand Journal of Sociology 32(3):57-69.

Teitelbaum, Michael S. and Jay M. Winter. 1985. The Fear of Population Decline. San Diego: Academic Press.

Therborn, Goran. 1993. The politics of childhood: the rights of children in modern times. Pp.241-291 in F.G. Castles (ed.), Families of Nation.; Patterns of Public Policy in Western Democracies. Aldershot: Dartmouth.

Tsolidis, Georgina. 1995. Greek-Australian families. Pp.121-143 in R. Hartley (ed.), Families and Cultural Diversity in Australia. Sydney: Allen and Unwin.

van deKaa, D.J. 1996. Anchored narratives: the story and findings of half a century of research into the determinants of fertility. Population Studies 50(3):389-432. 
Vasta, Ellie. 1995. The Italian-Australian family: transformations and continuities. Pp.144-166 in R. Hartley (ed.), Families and Cultural Diversity in Australia. Sydney: Allen and Unwin.

Zimmermann, K. 1993. Labor responses to taxes and benefits in Germany. Pp.192-240 in A.B. Atkinson and G.V Mogensen (eds), Welfare and Work Incentives. Oxford: Clarendon Press. 